\title{
Baroque balconies and masks in eastern Sicily (Italy)
}

\author{
C. Gullo \& L. Battaglia \\ Department of Patrimony, Architecture, Urbanism, \\ University Mediterranea of Reggio Calabria, Italy
}

\begin{abstract}
The 1693 earthquake was a disastrous event that struck south-eastern Sicily, in southern Italy. The disaster damaged several towns such as Catania, Acireale, Noto, Ragusa, Siracusa, Scicli, Modica and Palazzolo, and destroyed the majority of their monuments. The degree and extent of the damage caused by the earthquake prompted an architectural revival in the towns of Sicily, a style that has become known as "Sicilian Baroque". Many of the public buildings, palazzi, cathedrals and churches were reconstructed in this style and at this time, these cities represented a considerable collective undertaking, successfully carried out at a high level of architectural and artistic achievement. One of the most representative examples of the Sicilian Baroque style are the balconies, supported by console brackets adorned with apotropaic masks; monumental portals with richly decorated voussoirs and keystones. This paper aims to investigate some of these elements: Palazzo Beneventano in Sicily, decorated with very expressive and grotesque apotropaic masks; the balconies of Palazzo Zacco in Ragusa with sculptures representing a mermaid and musicians playing maracas, flutes and trumpets; the balconies of Palazzo Nicolaci in Noto, in which every single console brackets is decorated in different ways: mermaids, winged horses, lions, cherubs; the balcony of Palazzo Judica Caruso in Palazzolo Acreide, the longest balcony in the world with its 27 console brackets. These architectural elements are very important in reporting the Baroque period of Sicilian's history and represent the culmination and final flowering of Baroque art in Europe. The understanding and awareness of historical values is important for treasuring and preserving this unique historic, and non-reproducible, heritage.

Keywords: Baroque architecture, balconies, portals, Sicily, 1963 earthquake.
\end{abstract}




\section{Effects of the 1963 eastern Sicily earthquake}

The last decade of the seventeenth century marks an important date in the urban and architectural history of eastern Sicily.

On that period of time a major earthquake struck a vast territory of the eastern part of Sicily, known as Val di Noto (Figure 1), with two violent shocks occurred over three days. The first event, the foreshock, occurred on January 9, at 4:30 local time with an estimated magnitude of 6.2 and a maximum perceived intensity of VIII-XI on the Mercalli intensity scale. The earthquake struck the south-eastern part of Sicily and, according to the study of Guidoboni et al. [1], the damage struck cities and villages like Augusta, Avola (the current Avola Vecchia), Noto (the current Noto Antica), Floridia and Melissa, where many buildings collapsed. Serious damage also affected the cities of Catania and Lentini. In Catania, already seriously damaged by the destructive eruption of Etna in 1669, many buildings and homes, as well as churches and monuments, were seriously damaged, and some houses were totally destroyed.

The quake was felt strongly in Messina and Malta, but it did not cause any damage, and was also lightly felt in Palermo [2].

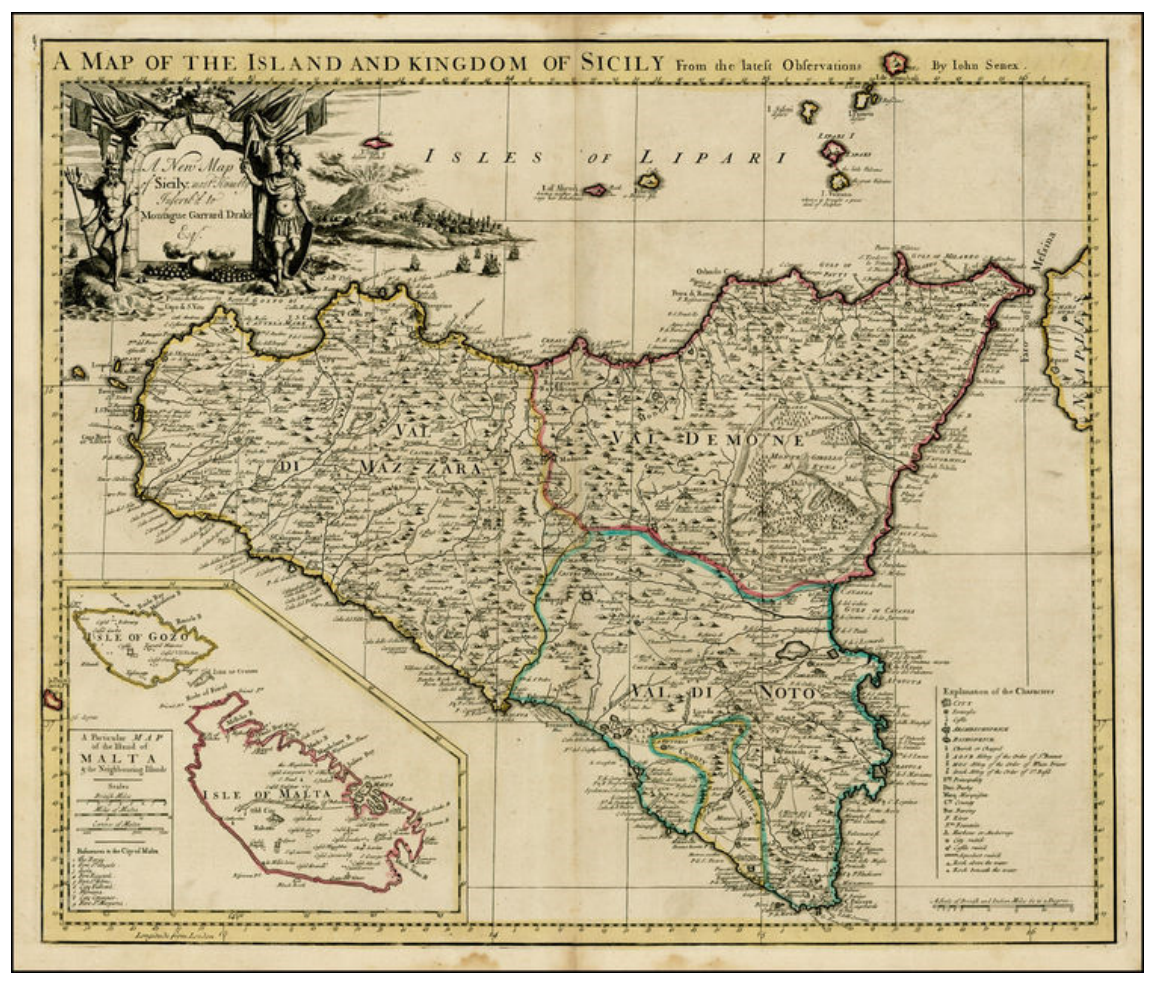

Figure 1: Map of the Island and Kingdom of Sicily by John Senex, 1721. 
The main shock occurred two days later, on January 11 at 9:00 p.m. (local time). The 7.4 magnitude earthquake provoked disastrous effects.

The severity of these effects was due to the fact that the buildings were weakened by the previous earthquake.

It is also true, however, that the area affected was much wider than the one struck by the first earthquake (about 14,000 square kilometers) [3]. The entire eastern Sicily was seriously affected. Collapses and serious damage occurred to Messina and the Tyrrhenian coast (Patti and Nose), northward, and southward to Malta.

Widespread damage and significant were found in Reggio Calabria, Agrigento and even in Palermo, located more than $150 \mathrm{~km}$ from the epicenter. Lighter damage occurred to the Aeolian Islands and in some towns in the central and southern Calabria (Figure 2).

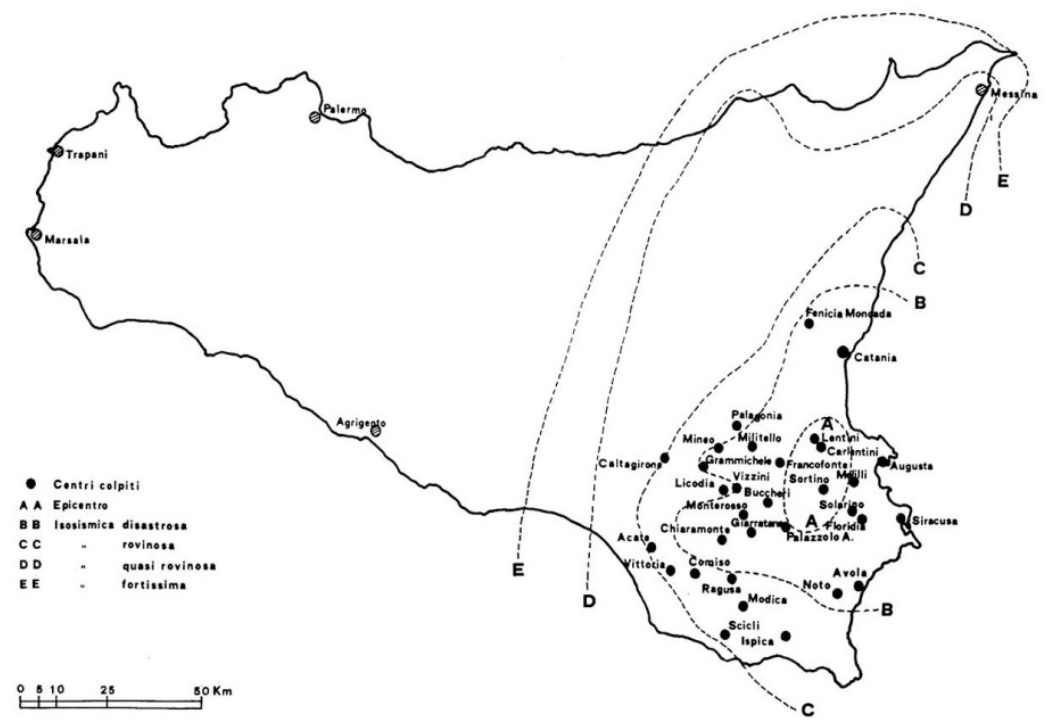

Figure 2: The main cities and towns destroyed by the 1693 earthquake.

The foreshock caused hundreds of victims, but the main shock killed thousands of people. In Modica 3,400 inhabitants died out of 18,203, while in Ragusa the victims were 5,000 out of 9,9446. Two hundred people died in Vittoria out of 3,950 and 2,000 in Sicily out of 9,382; in Spaccaforno, the present Ispica, there were 2,000 victims out of 7,987. In Giarratana 541 inhabitants did not survive out of a total population of 2,981 and in Monterosso 232 people died out of a population of 2,340. After this "sorrowful tragedy" the entire area of Val di Noto was completely decimated [4]. From that great destruction, however, has unleashed an extraordinary collective energy that has produced an original architectural language, recognized as the "Sicilian baroque" and now considered a UNESCO World Heritage Site. 


\section{Birth of the Sicilian Baroque style}

The reconstruction of January 1693 occurred near the end of Spanish rule, and was led by the Duke of Camastra, Spanish viceroy of Sicily.

The Duke adopted the new trends in town planning and, rather than rebuild following the medieval town principles of cramped narrow streets, decided that the new rebuilding would offer wider main streets that crossing each other, and spacious squares.

The cities affected by the earthquake were in fact re-built with rational town planning: straight streets intersecting to form small quadrilateral city blocks, known as cuadricula or damero [5] in which palaces were built with the purpose of giving the streets a focal point and a majestic perspective. This design followed models that had been already experienced and tested in Sicily in the past centuries. The new cities were re-built either in the form of huge extensions to the damaged cities (like Palazzolo Acreide) or completely new cities built from scratch in different sites, like Noto (Figure 3).

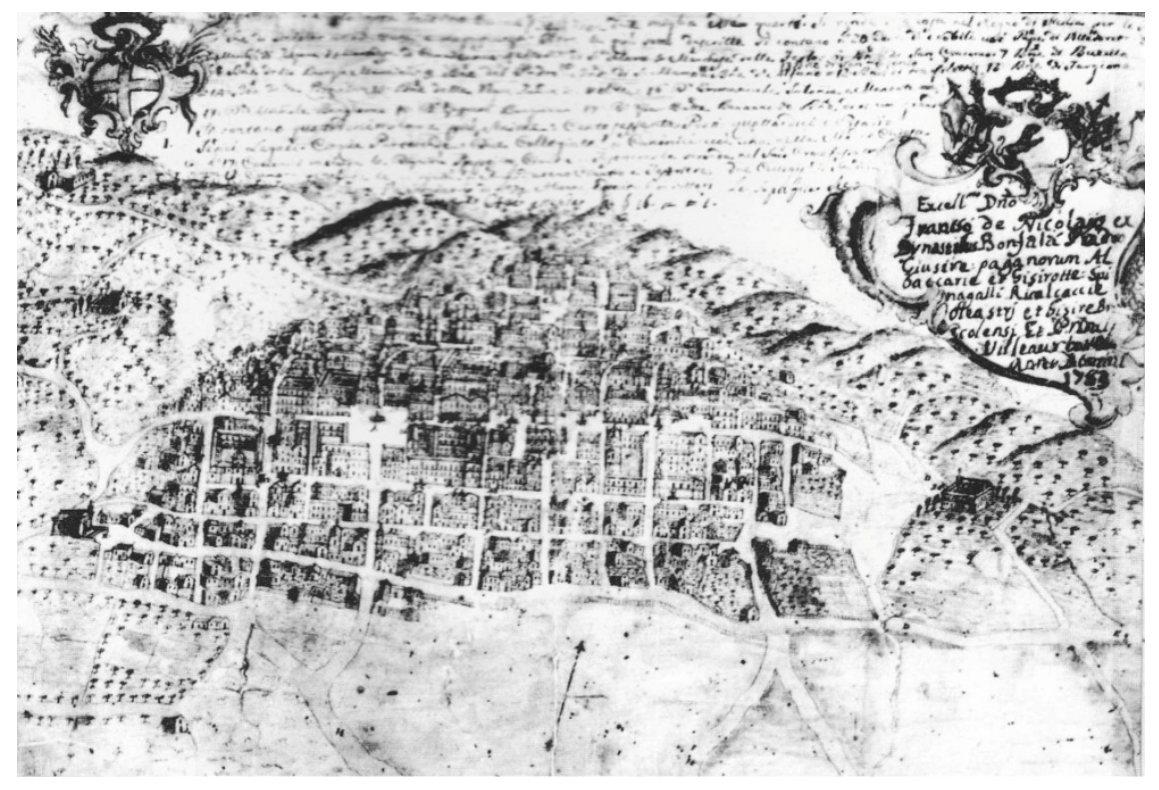

Figure 3: Map of Noto, 1705.

Due to the almost total destruction of the cities, the architects had the chance to carry out their dream to build an entirely new ideal city with a new, different style. Following the 1693 earthquake, foreigner architects (many of whom trained in Rome, Napoli and Florence) and local designers and artists, created a new style which to some extent departed from the movements then prevalent in Rome, Madrid and, a few years later, in Sicily [6]. 
The new style, known as "Sicilian Baroque" style is both popular and erudite, strongly characterized and deeply rooted in the territory. The Sicilian Baroque was in fact influenced by the "autochthonous" architectural tradition (the island's previous Gothic and Islamic traditions) and by the late Renaissance, and it is recognizable not only by its typical Baroque curves and flourishes, but also by its apotropaic masks that with their sensuous, ironic, and monstrous forms both captures and repels the violence of the earthquake [7].

While the heavy detail is extravagant and potentially gaudy, there is a playfulness and curiosity that makes the buildings fascinating to contemplate. "The buildings conceived in the wake of this disaster expressed a light-hearted freedom of decoration whose incongruous gaiety was intended, perhaps, to assuage the horror" [8] of the earthquake.

Each town in the Val di Noto province contains one or more examples of Sicilian Baroque architecture that has given Sicily a unique architectural identity [9]. The striking results are well exemplified by the locations that UNESCO selected in 2002 for its World Heritage List: Ragusa, Modica, Sicily, Noto, Palazzolo Acreide, Catania, Caltagirone, Militello in Val di Catania.

\section{Some examples of Sicilian Baroque masks and balconies}

The ornaments that decorate the palaces in eastern Sicily are apparently far from the concept of art and architecture, but this point of view can be unequivocally refuted after visiting Val di Noto, the Baroque Valley.

Balconies, shelves and frames that enrich and decorate the palaces, become the emblem of the baroque decoration of many of these buildings.

In particular, façade balconies, supported by corbels made out of successive courses of stonework, or by large wooden or stone brackets, were ornate with apotropaic masks.

These architectural decorations are used to "mask" and "disguise" the technical elements, and then to transform an object with structural function in an ornamental artifact. Also, the masks had an anthropological and magical significance, from which the adjective apotropaic. The adjective apotropaic (from Greek $\alpha \pi 0 \tau \rho \varepsilon ́ \pi \varepsilon v$ ) means "avert", "banish": monstrous faces, with horns and long tongues were used to ward off evil spirits. The use of this kind of masks to decorate portals and balconies belongs to the ancient culture. People from ancient times believed that the portals and windows were particularly vulnerable to the entry or passage of evil. Listed below, are some representative palaces, examples of the Sicilian Baroque style.

\subsection{Palazzo Beneventano (Sicily)}

It is located on the slopes of the Colle di San Matteo, in Sicily, in a central position between the ancient city located on the hilltop, and the eighteenth-century modern city that lies in the valleys of Santa Maria La Nova and San Bartolomeo. 
The charming Palazzo Beneventano, one of the 700 most important baroque monuments and most original baroque palace of the province of Ragusa, has been listed in 2002, as a UNESCO World Heritage Site.

Characteristic "irreverent" masks adorn the two monumental facades linked by a corner pilaster, which acts as a trait d'union.

Decorations consist of ashlars side pilasters, enriched on top by two mask representing two Moor's heads. In the bottom of the pilaster there is a statue representing St. Joseph (Figure 4).

The building is characterized by the balconies with curved cast iron railings supported by console brackets representing fantastic animals and masks. Among the masks, there are some representing black Africans. These sculptures were very rare in the Sicilian iconography because, until then, just Saracens and Moors were represented in the ornaments [10].
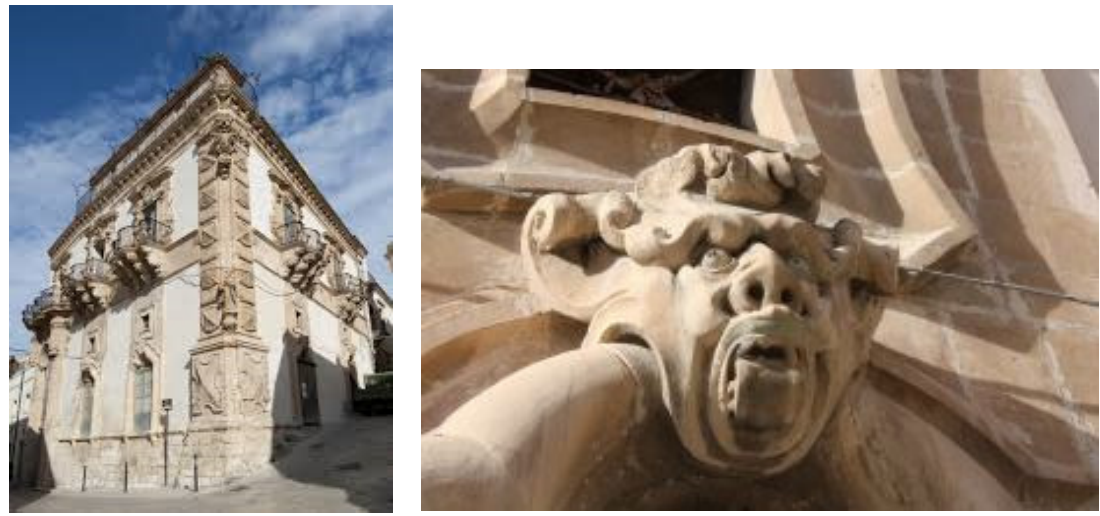

Figure 4: Palazzo Beneventano and on the right, of the detail of one of the masks.

\subsection{Palazzo Zacco (Ragusa)}

The palace is part of the list of 18 monuments Ragusa included in UNESCO sites of Val Di Noto. It was built in the second half of the eighteenth century by Baron Melfi of St. Anthony and then bought by the Zacco family at the end of the nineteenth century [11].

Located on the border of the new Ragusa (built from scratch after the 1693 earthquake), the building has two façades with six large balconies. In the corner pilaster is the Melfi family crest outlined by a frame of acanthus leaves on which rests a cherub. On the main façade there are three balconies: the central one is supported by the two grand entrance pilaster with Corinthian capitals.

The side balconies are supported by stone brackets representing musicians with grotesque expressions.

The middle stone bracket of the right side balcony is very original. The bracket has two sculptures representing a musician playing maracas and a griming face (Figure 5). 
In the side façade there are another three balconies. The one in the middle, leaning on five stone brackets, is the most charming; the stone bracket at the center, larger than the others, represents a mermaid, while the other four represent musicians playing flutes and trumpets.

Today the palace is owned by the municipality of Ragusa and it is a farmers' museum with a small exhibition of craft tools.
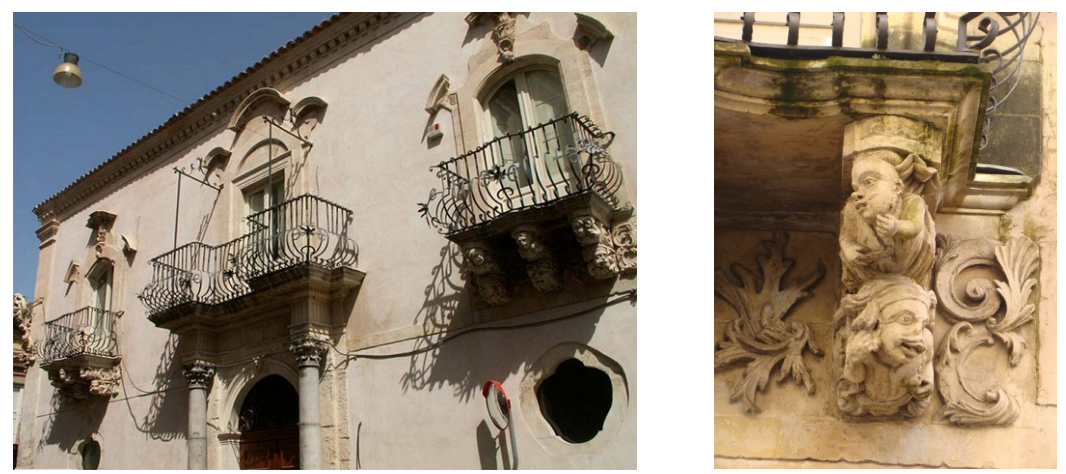

Figure 5: Palazzo Zacco and on the right, of the detail of one of the masks representing a musician playing maracas.

\subsection{Palazzo Nicolaci (Noto)}

Palazzo Nicolaci - Villadorata, Noto, is the urban residence of noble family Nicolaci. In 1701 the family Nicolaci acquired the title of "Barons of Gisira and Bonfalà" buying feudal lands with noble titles attached.

Corradino Nicolaci led the construction of the first building. The coat of arms of the family is the rampant greyhound leaning on a column.

The Palace, in Baroque style has about 90 rooms and three Salons, is the result of the handiwork of several skilled architects, imitating the explosion of Baroque at that time, with its flamboyant world of the imagination. The heraldic symbol shown on the family arms is a greyhound resting on a column, signifying trust, strength and loyalty.

The balconies resemble those of the Palace of Baron Trezzano, Noto Antica.

The building is characterized by a sequence of cast iron balconies, with railings decorated "a petto d'oca" and supported by stone corbels with grotesque figures representing mermaids (Figure 6), sphinxes, lions, hippogriffs, winged horses and angels.

The central mask of the balcony in the main façade, called "the Moors", resemble the figure of Giacomo Nicolaci holding a flute in his left hand, reminding us that in 17th century Europe human knowledge was represented by a man with a flute, not a musician but a wise man who did not allow himself to be enchanted by the beauty of the music [12].

Defined as the most beautiful balconies in the world, they have become the icon of the late baroque city of the Val di Noto and the cultural district of the southeastern Sicily. 

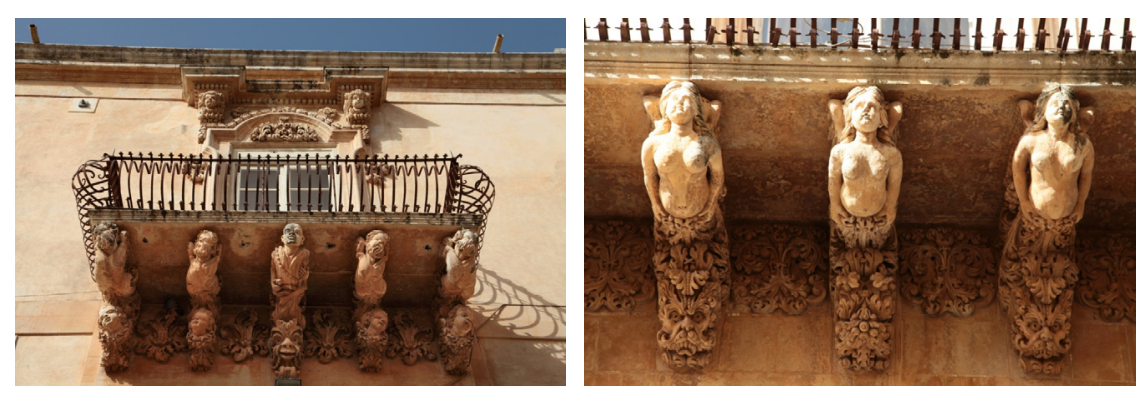

Figure 6: Stone brackets representing the mermaids in Palazzo Nicolaci.

\subsection{Palazzo Judica Caruso (Palazzolo Acreide)}

Palazzo Judica Caruso, located in Palazzolo Acreide in the district of St. Anthony, was built just after the earthquake of 1693 by Don Pasquale Lombardo, first owner until his death in 1748 .

On the cornice of the central window there is the Lombardo family crest representing the "family's weapons", also present in archival documents as a sigillum [13].

The palace is today called in different ways, according to the various owners: Palazzo Càfaci, Palazzo Judica, Palazzo Caruso.

The balcony is now the main attraction of the palace. Is the longest baroque balcony in the world, with 27 stone brackets, representing a combination of different masks and figures (Figure 7).
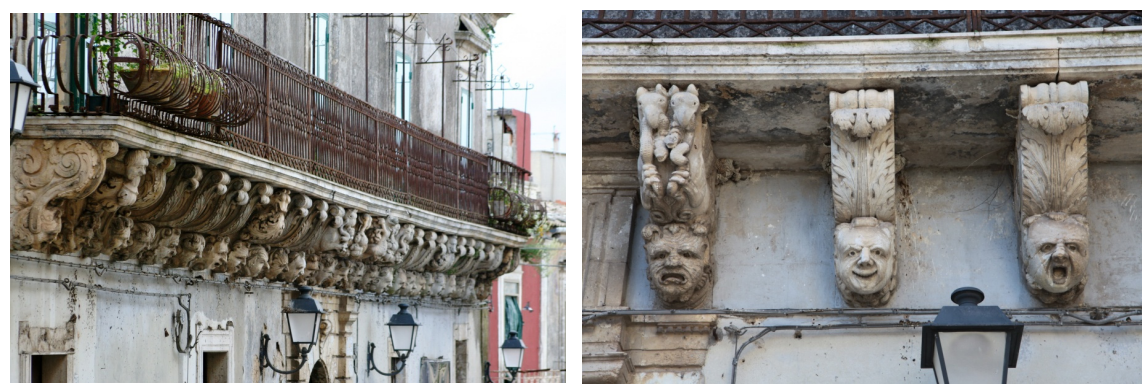

Figure 7: The balcony of Palazzo Judica Caruso. The longest of its kind, supported by 27 finely sculptured brackets.

The building is the handiwork of the local architect Don Giuseppe Ferrara, a leading figure of Palazzolo post-seismic reconstruction. The cast iron balconies, with railings decorated "a petto d'oca" were made by the Syracusans Giovanni Fiore and Saverio Scatà, although after a restoration work carried out during the nineteenth century, the original design has been changed [14]. 


\section{Memories of a stonecutter}

The stonecutters played a fundamental role during the post-seismic reconstruction. During the construction of humble houses and noble palaces, the architect was often replaced by stonecutters. They usually followed architectural examples already tested. However, for the main façade design, they have managed to create original masterpieces that today, are considered unique examples of the constructive activity in the south-eastern Sicily.

The raw material for the production of shelves, capitals, and arches, was locally carved, thanks to the excellent quality of the Sicilian limestone and sandstone.

To better understand the methods of carving and creating stonemasonry in Val di Noto, and in particular in Palazzolo Acreide, it is helpful to read the statement of the craftsman Santo Calleri, a modern artisan following in his ancestors' footsteps, interviewed by Paolo Giansiracusa.

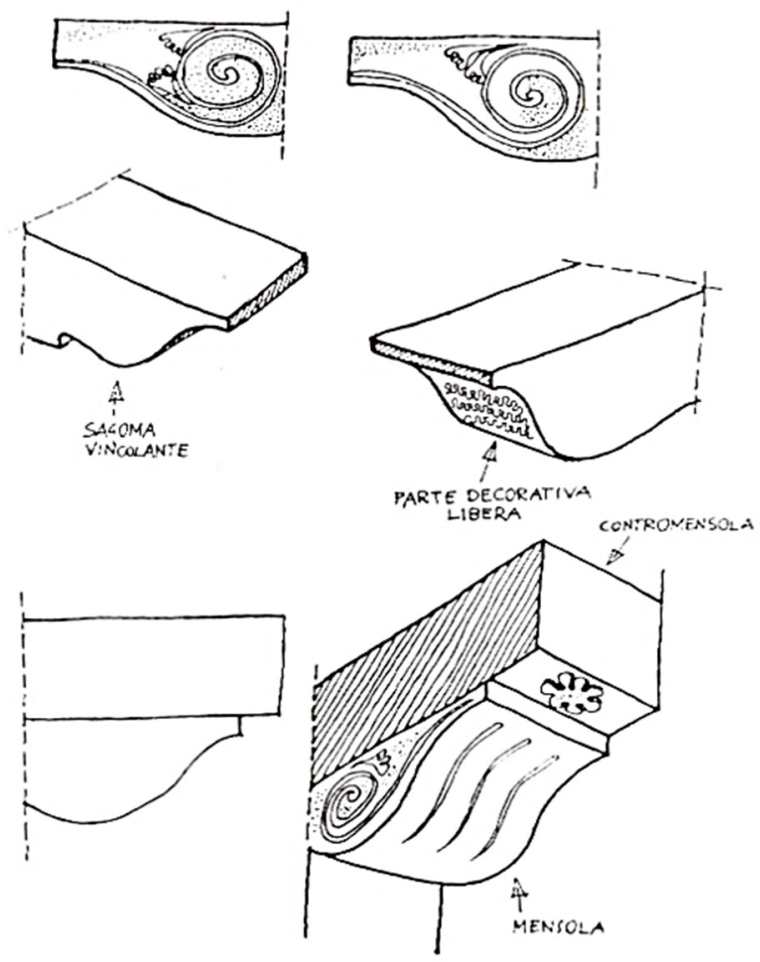

Figure 8: Stone bracket carved by Santo Calleri in a sketch made by Paolo Giansiracusa.

The craftsman is a member of one of the oldest families of Sicilians stonecutters. Among his ancestors there was Paolo Calleri, one of the most important craftsman during the nineteenth century. 
Reading the interview, it is possible to understand the details that explain the work behind these great masterpieces, which can be seen along the streets of Val di Noto. The thickness of the blocks depends on the masonry in which the blocks (the brackets) are to be placed, and are all originally made of the same size, and then completed on the construction site. The designs of brackets and capitals were learned in schools that the young stonecutters attended in the evening. During the day, however, they worked in the construction sites.

The shapes of these brackets were made on sheets of "carton-cuoio" that were laid against the raw stone before being carved [15].

\section{Conclusions: our past is our future}

The Baroque style is predominant in this land full of art, and in great part still unknown and the masks, moreover, are the most representative elements of the Sicilian baroque architectures. Almost everywhere in the eastern Sicily, from Ragusa to Scicli, from Modica to Noto, from Catania to Syracuse, the mask represents figures linked with the magical and mystical world.

These elements must be preserved because they constitute the evidence of one of the most significant historical periods that characterize the history of Sicily and, all together, represent the cultural value that allows to maintain the identity and integrity of a whole region.

Our architectural heritage is a unique resource, an irreplaceable expression of the richness and diversity of a country and characterizes its past and the identity of its people. It is the soul of the people who make the places alive and unique, not as mere places, but as places in which the genius loci lives together with the souls of men and women.

\section{Acknowledgements}

Attributions: L. Battaglia authored paragraphs 1 and 2; C. Gullo set up the research framework and authored paragraphs 3,4 and 5 .

\section{References}

[1] Guidoboni, E., Ferrari, G., Mariotti, D., Comastri, A., Tarabusi, G., \& Valensise, G. (2007). CFTI4MED, CATALOGUE OF STRONG Earthquakes in Italy (461 B.C.-1997) and Mediterranean Area (760 B.C.1500), INGV-SGA, http://storing.ingv.it/cfti4med

[2] Condorelli, S., The Reconstruction of Catania after the Earthquake of 1693, Proc. Of the $2^{\text {nd }}$ Int. Congress on Construction History, eds. Cambridge University: Cambridge, pp. 799-816, 2006.

[3] Puleo, T. J., Baroque disruption in Val di Noto. The Geographical Review. 100 (4), pp. 476-493, 2010.

[4] Baratta, M., I terremoti d'Italia. Saggio di storia, geografia e bibliografia sismica. Fr.li Bocca: Torino, 1901. 
[5] UNESCO, www.patrimoniounesco.it/VALDINOTO/index.htm

[6] Azzaro, R., Barbano, M. S., Moroni, A., Mucciarelli, M., \& Stucchi, M., The seismic history of Catania. Journal of Seismology. 3 (3), pp. 235-252, 1999.

[7] Blunt, A., Sicilian Baroque. Weidenfeld and Nicolson: London, 1968.

[8] Miers M., Power and Glory: Paintings of the Sicilian Baroque. Country Life, $1,2004$.

[9] Dufour, L., Raymond, H., 1693: Val di Noto: La rinascita dopo il disastro. Domenico Sanfilippo Editore: Catania, 1994.

[10] Casamento, A., La qualità del progetto urbano in Sicilia tra Sei e Settecento. Annali del Barocco in Sicilia Pompeo Picherali Architettura e città fra XVII e XVIII secolo. Gangemi Editore: Siracusa, pp. 47-52, 1997.

[11] Trigilia, L., La valle del barocco: le città siciliane del Val di Noto, "Patrimonio dell'umanità", Domenico Sanfilippo: Catania, 2002.

[12] Ide, J. J., Noto - the Perfect Baroque City. Journal of the Royal Institute of British Architects, 66, pp. 10-15, 1958.

[13] Antoci, G., I monumenti del tardo barocco di Ragusa, Nonsolografica: Ragusa, 2003.

[14] Lombardo, L., Don Pasquale Lombardo e il suo Palazzo. Studi Acrensi (1984-1995), ed. Flaccavento: Siracusa, pp. 175-182, 1999.

[15] Giansiracusa, P., L'attività degli Scalpellini nella Sicilia Orientale, ed. Morrone Editore: Siracusa, pp. 35-46, 2001. 